\title{
Meta-analysis of determinants of venture capital activity
}

\author{
Adel Dalal
}

\section{A B S T R A C T}

Objective: The objective of the article is to quantitatively systematise the existing literature on country-level venture capital (VC) activity and find the sources of discrepancy in previous studies.

Research Design \& Methods: This article collects studies that focus on venture investments across countries. I retrieved 840 estimates reported in 30 studies and analysed them using meta-analysis methods. The average effect sizes were estimated and corrected for publication bias. Then, I controlled for 24 aspects of study design and data in order to find the cause of differences in the primary results.

Findings: The findings suggest that the average effect of the studied determinants of VC activity is positive and significant. Technological opportunities, macroeconomic conditions and financial market development show the highest effect which confirms the previous research. The choice of data source influences the results in a systematic way, while model specification does not affect the reported coefficients. The results showed that drivers of VC in developed and developing countries do not differ significantly, the same finding is obtained for various stages of VC.

Implications \& Recommendations: The analysis of existing literature delineates the research agenda for further enhancing the institutional, technological, and macroeconomic descendants of VC. It revealed that informal institutions have been studied scarcely and deserve more attention in future research. The findings show that VC is not heterogeneous across the stages of investment which is important for venture fund management. By scrutinizing different aspects of model design and data samples I provide methodological recommendations for further research.

Contribution \& Value Added: To my knowledge, this is the first meta-analysis of VC determinants. The research method allowed to quantitatively summarise previous studies and detect the between-study differences. This article collects all the coefficients of VC drivers that have been reported up to date while previous literature reviews focused on some limited sets of variables. The article contributes to existing theory by answering the questions regarding VC heterogeneity.

\begin{tabular}{ll}
\hline Article type: & research article \\
Keywords: & venture capital; literature review; meta-analysis; publication bias \\
JEL codes: & G24, L26, O50
\end{tabular}

Received: 1 March $2021 \quad$ Revised: 4 July $2021 \quad$ Accepted: 25 August 2021

\section{Suggested citation:}

Dalal, A. (2022). Meta-analysis of determinants of venture capital activity. Entrepreneurial Business and Economics Review, 10(1), 113-128. https://doi.org/10.15678/EBER.2022.100108

\section{INTRODUCTION}

The year of 2018 impressed with record figures of venture capital (VC) invested worldwide at over 250 billion USD (KPMG, 2018). In 2020, the market remained strong, defying concerns of a potential slowdown due to the pandemic. While the USA continue driving global VC, Asia ranks second in investment levels, raising nearly twice the amount European VC-backed companies did ( $21.1 \mathrm{bln}$ USD versus 12.1 bln USD) in the third quarter of 2020 (KPMG, 2020). The academic literature stresses the importance of a vibrant VC market. Lerner and Tag (2013) emphasize that the ability of VC investors to overcome information asymmetries and provide capital to innovative business boosts economic growth. Allen (2012) summarizes the positive effect of VC on welfare. Popov and Roosenboom (2013) and Popov (2014) find that VC increases the rate of new business creation. 
A growing number of studies answer questions regarding the VC industry's evolution and mounting investments. However, the evidence across studies is inconclusive, which creates obstacles in their interpretation and theory-building. Considering extant VC literature reviews, we observe an evolution from mostly descriptive works to structured articles with more thorough sample building. Apart from some prominent surveys published recently (Wallmeroth et al., 2018; Devigne et al., 2018; Tykvová, 2018; Hahn et al., 2019; Grilli et al., 2019), most reviews fail to detect inconsistencies in primary studies. Although reviews have evolved from descriptive to structured articles, the majority utilize qualitative methods, while quantitative research of VC literature remains scarce.

The novelty of this article is that it provides a quantitative analysis of previous studies on VC determinants across countries. Given the sufficient volume of cross-country research meta-analysis was used as a method, which, to my knowledge, is the first meta-analysis in this discipline. By combining data from individual studies, I calculate effect sizes on a greater sample and correct it for publication bias, which allows for more precise estimates of underlying relationships (Glass, 1976). Meta-regression analysis provides statistical evidence on the causes of the variation in results in primary studies, which could not be done in a qualitative literature review. This study also covers all determinants of the VC market activity that were analysed before, while former reviews focus on specific drivers. Moreover, I have included the most recent studies, many of which have not been used in earlier reviews.

Previous surveys detect methodological issues in VC research. Tykvová (2018) argues that different results may be obtained from different proxies and econometric methodologies. Data source may also introduce a statistical bias due to differences in definitions of VC across countries (Devigne et al., 2018). Other issues include heterogeneity of investors and cyclicality of the VC industry, which may introduce biases in panel data analysis (Manigart \& Wright, 2013; Drover et al., 2017; Grilli et al., 2019). In general, authors argue that more comparative and replicative studies with independent datasets are needed to enhance accumulated knowledge (Cumming \& Vismara, 2017; Drover et al., 2017).

This meta-analysis addresses the aforementioned methodological issues. In the meta-regression, I will control for data sources and econometric models used in each primary study to see if they influence the effect values. Similarly, the stage of VC investments is used as a moderator variable to provide evidence on the heterogeneity of investors since many authors defined it as an open question in VC research. To shed light on the possible influence of institutional context, I differentiate between samples of developed and emerging countries utilised in primary studies.

This article has several research objectives. Firstly, it systematizes the empirical evidence on the determinants of VC activity. I conduct a keyword search in the main databases and complement it with a manual search in references, which yielded a comprehensive set of studies produced to date. Secondly, I analyse VC determinants using combined datasets, which significantly decreases sampling error and provides an overall reliability which is unavailable from any single study alone. It also helps to cover all variables that were studied in the existing literature. The result of the analysis are mean effect sizes of each variable corrected for heteroskedasticity and publication bias. The third objective is to observe factors influencing the variation of coefficients across studies. In order to do so, I run a metaregression on the characteristics of articles in the sample. These moderators include data characteristics and methodology. While previous literature reviews critically appraise the current state of the literature, this study reports the statistical evidence on existing gaps.

The remainder of this article will be organized as follows. Firstly, I will review the previous literature on country determinants of VC and formulate hypotheses. Then, I will present how the sample was collected and discuss the meta-analysis methodology. The next part will cover effect sizes that have been obtained and the results of meta-regression analysis. In conclusion, I will discuss the limitations of the study and propose avenues for future research.

\section{LITERATURE REVIEW}

There is an ongoing academic endeavour in determining the effects of country characteristics on VC activity. The modern stream of literature on VC investments applies a supply and demand model initially 
developed by Black and Gilson (1998) and Gompers and Lerner (1999). Studies propose a wide range of supply-side and demand-side variables that may influence the volume of VC investment in a country.

This review considers all variables found in the existing literature. I also added variables that have been overlooked by the previous literature reviews, which include the country's FDI, along with the annual volume of trade and exports. As most variables considered in primary studies are proxies for a handful of underlying factors, I grouped them into meta-categories. These meta-categories follow the classification of Grilli et al. (2019) and consist of three main clusters: 1 ) institutions (formal and informal); 2) technological opportunities; 3 ) macroeconomic conditions. In the next subsections, I consider each category and build relevant hypotheses.

\section{Formal Institutions}

Institutions in the form of two groups, formal and informal, were introduced by North (1990). Formal institutions are particularly important in managing the risks of venture investing. High levels of uncertainty in the VC environment, coupled with potential information asymmetry between investors and entrepreneurs, force venture capitalists to regularly utilise risk mitigation mechanisms. The efficiency of such mechanisms is dependent upon well-functioning formal institutions. Formal institutions were abundantly studied in VC literature. They may be categorized in regulatory conditions (including fiscal policy and labour markets), government quality, and financial markets.

The role of the legal environment in mitigating risks was established in the extant research (Lerner \& Schoar, 2005; Armour \& Cumming, 2006; Hazarika et al., 2009; Cumming et al., 2010; Aggarwal \& Goodell, 2014). States with relatively low or unreliable investor protection (i.e. civil law countries) develop smaller $\mathrm{VC}$ markets in comparison to common law countries. Protection of investor rights and disclosure requirements aim to reduce information asymmetries and opportunistic behaviour among involved parties (Grilli et al., 2018; Jeng \& Wells, 2000; Cumming et al., 2016). An availability of contract instruments, such as convertible bonds and limited partnership contracts, improves the governance of entrepreneurial firms (Cumming, 2011). With regard to fiscal policy, previous studies show that low corporate tax results in higher returns for venture capitalists, while reduced capital gains tax produces profits for equity type of investing, benefiting both VC managers and entrepreneurs (Armour \& Cumming, 2006; Popov \& Roosenboom, 2013). An empirical analysis concludes that high tax rates seem to be one of the major obstacles for venture industry growth in Europe (Grilli et al., 2018). The labour market rigidity shows influence on the demand side of the VC industry. The strict labour regulation is seen to increase costs for young firms and lower the entrepreneurial base, as was concluded by the majority of existing studies (e.g., Jeng \& Wells, 2000; Cumming, 2011; Bonini \& Alkan, 2012) with some exceptions (Grilli et al., 2018).

In order to enforce the aforementioned regulatory tools, a high level of governance is needed. The existing studies provide evidence on the role of government in cross-country variation of VC. The impact of government quality holds for both global (Li \& Zahra, 2012) and European context (Grilli et al., 2018).

Financial market development is one of the most studied formal institutions. It comprises of domestic stock market capitalization, exit markets size, and performance of stock indexes. The category is considered as a determinant of the supply side of VC market. The ability to realize gains through exits is critical to VC funds as it generates a return for limited partners and increases the chance of future funds. However, the existing literature does not provide clear evidence on the impact for different stages of VC. Among the first to distinguish between different VC stages were Jeng and Wells (2000). Their model shows the positive impact of IPO market volume on the activity of late-stage VC. Later, Bonini and Alkan (2012) highlight the positive role of IPOs on early-stage deals. Schertler (2003) and Cumming (2014) show the positive effect of stock market capitalization on early-stage investments, while Félix et al. (2013) observe the significance of this variable only for later stages. Regarding geographical context, the mergers and acquisitions (M\&A) volume has a bigger influence in Europe, in which the initial public offering (IPO) market is less vibrant (Félix et al., 2013; Grilli et al., 2018).

H1: Developed formal institutions - proxied by high investors legal protection, low taxation, flexible labour market, high government quality, and developed financial market - have a positive effect on a country's volume of VC investments. 


\section{Informal institutions}

Compared to formal institutions, informal institutions were overlooked in academic literature. They describe characteristics of individuals and refer to the demand side of the VC market. Modern research highlights the role of entrepreneurship, which represents country-level entrepreneurialism, social capital or trust, uncertainty avoidance, individualism, and power distance (Hain et al., 2016). Drover et al. (2017) focus on informal institutions confirming they can shape VC investment patterns. The informal attributes, such as social networking, play an important role (Masiak et al., 2020), especially elevated in weak legal environments (Ahlstrom \& Bruton, 2006; Lingelbach, 2015). The cross-country variation in the levels of entrepreneurship is an important factor in VC investments (Romain \& van Pottelsberghe, 2004), yet the effect of entrepreneurship may be mediated by other institutional variables. Wessendorf et al. (2020) demonstrate the importance of entrepreneurial spirit on the firm level.

With the increasing internationalization of $\mathrm{VC}$, more studies focus on cultural distance and trust, but the findings are inconclusive. Nahata et al. (2014) showed that cultural distance positively affects VC success, Li et al. (2014) found the opposite effect. There is a negative relationship between trust and exit pay-out, but more sophisticated venture capitalists tend to invest more in low trust countries (Bottazzi et al., 2016).

H2: Developed informal institutions, including entrepreneurship, individualism, trust, and low uncertainty avoidance, have a positive effect on a country's volume of VC investments.

\section{Technological opportunities and macroeconomic conditions}

A large body of literature considers the link between innovation and VC. There are various proxies for technological opportunities across academic works such as patents, public and private R\&D expenditures, and R\&D capital stock. Recent studies proxy technological opportunities with innovation index (e.g., Sargon \& Katircioğlu, 2019). The use of proxy seems to affect the results. It was shown that innovation boosts venture investment activity in European high-income countries. Ning et al. (2019) show the positive impact of patent creation on VC industry growth. At the same time, Grilli et al. (2018) find a negative correlation between private R\&D investments and VC activity. Authors explain the negative relationship with the choice of the measure used. Namely, the more funds private companies invest in $R \& D$, the less they might be interested in start-ups as a source of technological innovation, which reduces the volume of acquisitions, one of the key VC exit mechanisms. In general, technology is a booster for the business creation and demand for VC.

H3: A high level of technological opportunities, measured by the volume of R\&D, patents creation, and innovations, has a positive effect on a country's amount of VC investments.

The GDP growth rate is the most studied driver of VC, but the empirical evidence on its significance is mixed (e.g. Jeng \& Wells, 2000; Black \& Gilson, 1998; Hain et al., 2016). Many studies show a procyclical nature of VC market with an increasing volume of investments in times of economic expansion (e.g., Jeng \& Wells, 2000; Ning et al., 2019). At the same time, Sargon and Katircioğlu (2019) do not find any significant effect of this variable in European countries. Mustafa and Mazhar (2020) show that GDP growth along with inflation rate are influential in the Indian VC market.

H4: Favourable macroeconomic conditions, including a growth of GDP and volume of trade, have a positive effect on a country's volume of VC investments.

\section{RESEARCH METHODOLOGY}

\section{Data selection}

The collection of data and research methodology was implemented with the compliance of reporting guidelines for meta-analysis in economics (Havranek et al., 2020).

As the first step, a key word search was completed in Web of Science and Scopus databases and Google Scholar search engine. I used the combination of keywords that were selected in order to 
exhaustively cover my research hypotheses. The process of building the search inquiry and all key words are presented in Table 1.

Table 1. Keyword search strategy

\begin{tabular}{|c|c|c|c|c|}
\hline Main keyword & venture & capital & determinants & institution \\
\hline Synonyms & private equity & investments & growth & market \\
\hline \multirow{3}{*}{} & & funding & country & exit \\
\cline { 3 - 5 } & & activity & structure & IPO \\
\cline { 3 - 5 } & & finance & analysis & regulation \\
\cline { 4 - 5 } & & & empirical & entrepreneurship \\
\cline { 4 - 5 } & & & disclosure \\
\cline { 4 - 5 } & & & corruption \\
\cline { 4 - 5 } & & & GDP \\
\cline { 4 - 5 } & & & & macro \\
\hline
\end{tabular}

Source: own study.

The date of the last search was 12.10.2020. No limits were set for the year of publication, database indexes, and publication status; anonymous records were excluded. Along with a keyword search, I scanned reference lists of included studies or relevant reviews. This procedure helped to ensure a more complete coverage of the topic by accounting for the variability of scholarly works.

In the second step, articles were evaluated according to eligibility criteria in line with the research hypotheses. After the screening of abstracts and checking for the availability of the full texts, 167 unique contributions were assessed following the inclusion rules from Table 2.

Table 2. Eligibility criteria for selected studies

\begin{tabular}{|c|l|l|}
\hline No. & \multicolumn{1}{|c|}{ Criteria } & \multicolumn{1}{c|}{ Description } \\
\hline 1. & Dependent variable & Dependent variable is country-level venture investments across all stages of VC. \\
\hline 2. & Empirical study & Empirical study provides concrete evidence on the relationship between variables. \\
\hline 3. & Data & $\begin{array}{l}\text { Statistical coefficients, number of observations, standard errors (SE) or t-statistics } \\
\text { are reported. }\end{array}$ \\
\hline
\end{tabular}

Source: own study.

The first criterion specified the country-wide scope of the study and a definition of dependent variable. In order to comply with my research objectives, I excluded works that do not distinguish between VC and private equity funds. In order to draw valid conclusions on the phenomenon under investigation, I limited the sample to empirical studies. The last criterion specified that the empirical articles report statistics that can be converted into effects sizes that include beta coefficients, SE or $\mathrm{t}$-statistics and number of observations. As a result, 30 primary articles were selected, which yielded 840 observations for the meta-analysis.

\section{Research methods}

Coefficient estimates and SE were collected from the primary studies. Given the broad set of proxies in the selected articles, it is worthwhile to recalculate them to a common metric. I transformed the adjusted estimates into partial correlation coefficients (PCC) following the Equation 1. The choice of PCC was driven by the wide use of the coefficient in recent meta-analysis studies (Irsova \& Havranek, 2013) and the nature of variables under study. According to Stanley and Doucouliagos (2012), PCC is a unitless estimation of the size and direction of the association between two factors holding other variables constant.

where:

$$
P C C=\frac{t}{\sqrt{t^{2}+d f}}
$$

$P C C_{i}$ - is an effect size measured by partial correlation coefficient;

$t$ - is the t-statistic of the coefficient from primary study; 
$d f$ - is the degrees of freedom collected from primary study.

Next, effect sizes were corrected for the presence of publication bias. Publication bias is identified as a tendency of authors to report statistically significant results that support widely accepted theory (Stanley \& Doucouliagos, 2012). In order to quantify the degree of observed reporting bias, I employed the FAT-PET analysis shown in Equation 2. Funnel-asymmetry test (FAT) is based on hypothesis that effect sizes are independent of their SE in the absence of publication bias. The precision effect test (PET) indicates the effect beyond the publication bias.

where:

$$
P C C_{i}=\beta_{o}+\beta_{1} S E\left(P C C_{i}\right)+\varepsilon_{i}
$$

$P C C_{i}$ - is the effect size;

$S E\left(P C C_{i}\right)$ - is the $\mathrm{SE}$ of the effect size.

Equation 3 was estimated using OLS with clustered SE and weighted least squares (WLS). Stanley and Doucouliagos (2015) demonstrated that WLS provides superior estimates compared to fixed effect and random effects models when there is publication bias or small sample, which is the case in this study. In WLS, studies are weighted by the inverse SE of PCCs, assuming lower SE indicates more precise findings. Following the trend in meta-analysis, I collected estimates from all specifications in each study. As argued by Havranek et al. (2020) the omission of some specifications in the studies leads to arbitrary selection bias, while averaging of reported estimates discards a lot of information. Therefore, some articles presented a high number of coefficients, which may result in overweighting particular studies. To address this problem, I ran another WLS weighted by an inverse number of estimates in primary study (Astakhov et al., 2019; Zigraiova \& Havranek, 2016).

The final research objective was to observe factors influencing the variation of findings across primary studies. Although articles included in the sample had similar research questions, they varied in study designs that may have affected reported results. The presence of heterogeneity in economic research and its impact on estimated effects was confirmed by Stanley and Doucouliagos (2012). In the case of VC studies, the observed heterogeneity may stem from sample characteristics, model used, a measure of VC activity (dependent variable) and VC drivers (independent variables). To account for possible disparity, I ran a meta-regression based on FAT-PET Equation 3.

where:

$$
P C C_{i}=\beta_{o}+\beta_{1} S E\left(P C C_{i}\right)+\beta_{k} \sum_{i=1}^{n} X_{k i}+\varepsilon_{i}
$$

$S E\left(P C C_{i}\right)$ - is the SE of the effect size;

$X_{k i}$ - is the vector of mediator variables.

Table 3 provides an overview of mediator variables with their definitions and statistics. The obtained characteristics were transformed to dummy variables and divided in four groups: sample, model, dependent variable (DV), and VC driver.

The sample characteristics include dummies for the samples of developed countries (OECD members). The structure of VC market and the degree of institutional quality differ greatly between developed and developing states which can affect the results. Model characteristics capture regression model design. Most frequently used are GLS, OLS, fixed effects (FE), random effects (RE) and instrumental variables (IV). Other methods are used as a dummy reference. Moreover, I coded the measures of VC activity and whether it was scaled to GDP or population of the country. To control for the measure of VC driver in the study, I introduced ten dummy variables. Among them there were three macroeconomic determinants, (gdp, trade, and unemployment) and technological opportunities (tech). Fiscal policy, labour markets, other regulatory institutions, government quality, and financial markets represented formal institutions, while informal institutions were summarized in the variable informal. Publication characteristics were not included since the final sample consisted of studies taken from peer-reviewed journals. 
Table 3. Definition and summary statistics of variables

\begin{tabular}{|c|c|c|c|c|}
\hline Moderator variable & Definition & Obs & Mean & Std \\
\hline Effect size & Effect size & 840 & 0.111 & 0.213 \\
\hline Standard error & SE of the effect size & 840 & 0.085 & 0.039 \\
\hline \multicolumn{5}{|l|}{ Sample characteristics } \\
\hline Panel & $=1$ if panel data used & 809 & 0.105 & 0.206 \\
\hline Time-series & $=1$ if time-series data used (reference) & 31 & 0.262 & 0.314 \\
\hline Time dummy & $=1$ if time dummy was used & 208 & 0.086 & 0.128 \\
\hline EVCA & $=1$ if European VC Association is used as a data source & 430 & 0.085 & 0.159 \\
\hline TR & $=1$ if Thomson Reuters is used as a data source & 359 & 0.118 & 0.222 \\
\hline Other & $=1$ if other data source is used (reference) & 51 & 0.280 & 0.394 \\
\hline Developed & $=1$ if only developed countries are included in sample & 537 & 0.108 & 0.200 \\
\hline Global & $\begin{array}{l}=1 \text { if developed and developing countries are included in } \\
\text { sample (reference) }\end{array}$ & 303 & 0.115 & 0.235 \\
\hline \multicolumn{5}{|l|}{ Model characteristics } \\
\hline GLS & $=1$ if estimation method is GLS & 40 & 0.142 & 0.157 \\
\hline OLS & $=1$ if estimation method is OLS & 137 & 0.188 & 0.280 \\
\hline FE & $=1$ if estimation method is fixed effects & 329 & 0.101 & 0.220 \\
\hline RE & $=1$ if estimation method is random effects & 254 & 0.084 & 0.159 \\
\hline IV & $=1$ if estimation method is instrumental variables & 35 & 0.076 & 0.140 \\
\hline Other & $=1$ if other estimation method is used (reference) & 45 & 0.094 & 0.234 \\
\hline \multicolumn{5}{|l|}{ DV characteristics } \\
\hline Scaled & $=1$ if DV is scaled to GDP or population & 626 & 0.103 & 0.213 \\
\hline VC investments & $=1$ if $D V$ is VC investments & 576 & 0.112 & 0.241 \\
\hline VC funds raised & $=1$ if $D V$ is new VC funds raised & 79 & 0.067 & 0.110 \\
\hline Early VC investments & $=1$ if DV is early-stage VC investments & 172 & 0.131 & 0.125 \\
\hline Late VC investments & $=1$ if DV is late-stage VC investments & 8 & 0.076 & 0.175 \\
\hline Other & $=1$ if DV is another measure (reference) & 5 & -0.031 & 0.334 \\
\hline \multicolumn{5}{|l|}{ VC driver } \\
\hline Fiscal & $=1$ if fiscal incentives are used as a VC driver & 82 & 0.018 & 0.240 \\
\hline Labour & $=1$ if fluidity of labour markets is used as a VC driver & 23 & 0.053 & 0.103 \\
\hline Other regulatory & $=1$ if other regulatory institutions are used as a VC driver & 67 & 0.016 & 0.145 \\
\hline Government & $=1$ if governmental quality is used as a VC driver & 64 & 0.100 & 0.131 \\
\hline Fin. Market & $=1$ if financial market conditions are used as a VC driver & 194 & 0.133 & 0.218 \\
\hline Informal & $=1$ if informal institutions are used as a VC driver & 34 & 0.146 & 0.191 \\
\hline Tech & $=1$ if technological opportunities are used as a VC driver & 142 & 0.197 & 0.217 \\
\hline GDP & $=1$ if GDP is used as a VC driver & 177 & 0.126 & 0.225 \\
\hline Trade & $=1$ if trade is used as a VC driver & 22 & 0.148 & 0.163 \\
\hline Unemployment & $\begin{array}{l}=1 \text { if unemployment rate is used as a VC driver } \\
\text { (reference) }\end{array}$ & 35 & -0.044 & 0.149 \\
\hline
\end{tabular}

Source: own elaboration in Stata.

\section{RESULTS AND DISCUSSION}

The obtained mean effect sizes of VC drivers taken from 30 studies are summarised in Table 4. Hadi's (1992) multivariate outlier method was applied to filter effect sizes and SE. The procedure identified nine outliers, resulting in 831 observations in the general sample. Column 1 presents unweighted means measured by OLS with SE clustered at the study level. Columns 2 and 3 depict means weighted by the study's precision (inverse SE) and inverse number of estimates collected per study, respectively. 
All means are above zero indicating a direct association between country characteristics and the volume of VC investments. Technological opportunities, which present patents creation and R\&D sector of the country, show the highest effect on VC activity, which is consistent with previous research (Sargon \& Katircioğlu, 2019; Ning et al., 2019). Doucouliagos (2011) provides guidelines for the magnitude of effects in meta-analysis. The partial correlation coefficient (PCC) below 0.07 is considered negligible, between 0.07 and 0.17 shows a small effect, the range from 0.17 to 0.33 displays a moderate effect, and coefficients above 0.33 have a strong effect on dependent variable. In the meta-analysis technological opportunities exhibit the moderate effect, while other variables have the small effect on VC volume. There are no variables whose PCCs fall below 0.07 .

Table 4. Estimates of the country characteristics effect sizes

\begin{tabular}{|l|c|c|c|c|}
\hline \multicolumn{1}{|c|}{ Variable } & OLS (unweighted) & WLS (precision) & WLS (estimates) & Obs \\
\hline All variables & $0.106^{* * *}$ & $0.102^{* * *}$ & $0.105^{* * *}$ & 831 \\
\hline All institutions & $0.077^{* * *}$ & $0.085^{* * *}$ & $0.078^{* * *}$ & 458 \\
\hline Formal institutions & $0.072^{* * *}$ & $0.078^{* * *}$ & $0.076^{* * *}$ & 424 \\
\hline Financial market conditions & $0.104^{* * *}$ & $0.096^{* * *}$ & $0.102^{* * *}$ & 187 \\
\hline Macroeconomic variables & $0.134^{* * *}$ & $0.110^{* * *}$ & $0.155^{* * *}$ & 198 \\
\hline Technological opportunities & $0.190^{* * *}$ & $0.177^{* * *}$ & $0.163^{* * *}$ & 138 \\
\hline
\end{tabular}

Notes: ${ }^{* *},{ }^{* *}$, and ${ }^{*}$ denote statistical significance at the $1 \%, 5 \%$, and $10 \%$ level, respectively.

Source: own elaboration in Stata.

Following the methodology, the next step was to correct estimates for publication bias (see Table 5). The significant coefficient for SE shows the presence of selective reporting, while the intercept was the corrected underlying mean size. Column 1 presents the baseline OLS result of regressing coefficients of country characteristics on their SE. Column 2 shows the findings of WLS specification when the precision is used as the weight. Similarly, column 3 summarizes the results of WLS model weighted by inverse number of estimates per study.

The FAT-PET analysis supports the positive effect of country characteristics after adjusting for reporting bias. All models present the significant values for intercept for general sample and groups of institutions. The results show the negative publication bias for these variables, and at the same time, the corrected effect is higher than in Table 4. Similar results are obtained for financial markets, technological, and macroeconomic characteristics. Interestingly, WLS provides no evidence of selective reporting for these variables. Overall, there is a positive underlying relation between all country specific factors considered in the literature and VC activity. To evaluate the extent of selectivity, Doucouliagos and Stanley (2013) developed guidelines, in which substantial bias lies in the range between 1 and 2 . Thus, the presented evidence points to moderate publication bias shown by OLS and WLS estimators. Moreover, studies tend to underestimate the positive effect size of a country's institutional development, which was shown to be more pronounced than is commonly argued.

Previously, I scrutinized the literature and discussed the discrepancy in the existing studies' results. The final objective is to explore what drives this heterogeneity by testing the characteristics of the articles with meta-regression. Table 6 reports the results of meta-regression with all variables described in Table 3. The random effects multi-level (REML) model was tested to be the most appropriate. 
Table 5. FAT-PET estimates for country characteristics effect sizes

\begin{tabular}{|c|c|c|c|c|}
\hline FAT-PET & OLS & WLS (Precision) & WLS (Estimates) & Obs \\
\hline \multicolumn{5}{|c|}{ All variables } \\
\hline SE (reporting bias) & $\begin{array}{c}-0.204 \\
(0.429)\end{array}$ & $\begin{array}{c}0.201 \\
(0.479)\end{array}$ & $\begin{array}{c}-0.757 \\
(0.002)\end{array}$ & \multirow[t]{2}{*}{831} \\
\hline Constant (corrected effect) & $\begin{array}{c}0.123 \\
(0.000)\end{array}$ & $\begin{array}{c}0.089 \\
(0.001)\end{array}$ & $\begin{array}{c}0.171 \\
(0.000)\end{array}$ & \\
\hline \multicolumn{5}{|c|}{ Institutions } \\
\hline SE (reporting bias) & $\begin{array}{l}-0.650 \\
(0.022)\end{array}$ & $\begin{array}{c}-0.366 \\
(0.326)\end{array}$ & $\begin{array}{c}-0.866 \\
(0.001)\end{array}$ & \multirow[t]{2}{*}{458} \\
\hline Constant (corrected effect) & $\begin{array}{c}0.135 \\
(0.000)\end{array}$ & $\begin{array}{c}0.110 \\
(0.002)\end{array}$ & $\begin{array}{c}0.155 \\
(0.000)\end{array}$ & \\
\hline \multicolumn{5}{|c|}{ Formal institutions } \\
\hline \multirow[t]{2}{*}{ SE (reporting bias) } & -0.581 & -0.271 & -0.827 & \multirow[t]{4}{*}{424} \\
\hline & $(0.016)$ & $(0.395)$ & $(0.000)$ & \\
\hline \multirow[t]{2}{*}{ Constant (corrected effect) } & 0.125 & 0.097 & 0.150 & \\
\hline & $(0.000)$ & $(0.010)$ & $(0.000)$ & \\
\hline \multicolumn{5}{|c|}{ Financial market conditions } \\
\hline \multirow[t]{2}{*}{ SE (reporting bias) } & 0.121 & 0.429 & -0.238 & \multirow[t]{4}{*}{187} \\
\hline & $(0.778)$ & $(0.341)$ & $(0.569)$ & \\
\hline \multirow[t]{2}{*}{ Constant (corrected effect) } & 0.094 & 0.067 & 0.123 & \\
\hline & $(0.012)$ & $(0.004)$ & $(0.001)$ & \\
\hline \multicolumn{5}{|c|}{ Macroeconomic variables } \\
\hline \multirow[t]{2}{*}{ SE (reporting bias) } & 0.479 & 1.141 & 0.316 & \multirow[t]{4}{*}{198} \\
\hline & $(0.328)$ & $(0.023)$ & $(0.740)$ & \\
\hline \multirow[t]{2}{*}{ Constant (corrected effect) } & 0.096 & 0.045 & 0.130 & \\
\hline & $(0.035)$ & $(0.041)$ & $(0.068)$ & \\
\hline \multicolumn{5}{|c|}{ Technological opportunities } \\
\hline \multirow[t]{2}{*}{ SE (reporting bias) } & 0.550 & 0.822 & 0.881 & \multirow[t]{4}{*}{138} \\
\hline & $(0.126)$ & $(0.057)$ & $(0.188)$ & \\
\hline \multirow[t]{2}{*}{ Constant (corrected effect) } & 0.140 & 0.116 & 0.089 & \\
\hline & $(0.001)$ & $(0.005)$ & $(0.120)$ & \\
\hline
\end{tabular}

Notes: $p$-values are indicated in the brackets

Source: own elaboration in Stata.

As for study characteristics, it shows that the data source affects the results. It can be explained by the difference in the definitions of VC across data sources. Thomson Reuters (TR) and EVCA have negative coefficients, which means that the use of other sources such as local VC associations may inflate the obtained estimates. This concern was raised in previous studies. Cumming (2014) showed that the use of different datasets may lead to contradictory findings. The literature review by Devigne et al. (2018) highlights the inconsistency in definitions of VC across countries. Venture capital is cyclical, which is supported by the significant time dummy. The studies that control for the observed period show lower effect sizes.

There is no difference in the effect of VC drivers between developed and developing countries. In developed countries investors pay the same attention to country specific factors as in emerging countries. This is a surprising result, since recent studies focus on the differences across countries. Tykvová (2018) and Grilli et al. (2019) call heterogeneity within VC one of the hot topics in current scientific discussion. The lack of heterogeneity of determinants among countries may be explained by the growing internationalization of VC. Funds have developed versatile policies that they apply to different countries. This trend is reflected in a mounting number of articles on cross-border VC (Devigne et al., 2018; Tykvová, 2018). 
Table 6. Meta-regression analysis of moderator variables

\begin{tabular}{|c|c|c|c|c|}
\hline & REML & $p$-value & \multicolumn{2}{|c|}{$\mathrm{Cl}$} \\
\hline \multicolumn{5}{|c|}{ Sample characteristics } \\
\hline Panel & -0.015 & 0.751 & -0.110 & 0.079 \\
\hline Time dummy & -0.086 & 0.000 & -0.128 & -0.045 \\
\hline EVCA & -0.173 & 0.000 & -0.237 & -0.108 \\
\hline TR & -0.115 & 0.001 & -0.185 & -0.044 \\
\hline Developed & -0.001 & 0.980 & -0.060 & 0.059 \\
\hline \multicolumn{5}{|c|}{ Model characteristics } \\
\hline GLS & 0.113 & 0.020 & 0.018 & 0.207 \\
\hline OLS & 0.054 & 0.148 & -0.019 & 0.126 \\
\hline FE & -0.020 & 0.559 & -0.086 & 0.047 \\
\hline $\mathrm{RE}$ & 0.015 & 0.652 & -0.051 & 0.081 \\
\hline IV & 0.007 & 0.886 & -0.085 & 0.098 \\
\hline \multicolumn{5}{|c|}{ DV characteristics } \\
\hline Scaled & -0.026 & 0.231 & -0.069 & 0.017 \\
\hline VC investments & 0.088 & 0.338 & -0.092 & 0.268 \\
\hline VC funds raised & 0.055 & 0.561 & -0.130 & 0.240 \\
\hline early-stage VC & 0.104 & 0.262 & -0.078 & 0.286 \\
\hline late-stage VC & 0.170 & 0.138 & -0.055 & 0.395 \\
\hline \multicolumn{5}{|c|}{ VC driver characteristics } \\
\hline Fiscal & 0.043 & 0.288 & -0.036 & 0.123 \\
\hline Labour & 0.057 & 0.278 & -0.046 & 0.160 \\
\hline Other regulatory & 0.054 & 0.189 & -0.027 & 0.135 \\
\hline Government & 0.142 & 0.000 & 0.063 & 0.221 \\
\hline Fin. Market & 0.139 & 0.000 & 0.069 & 0.208 \\
\hline Informal & 0.172 & 0.000 & 0.082 & 0.262 \\
\hline Tech & 0.205 & 0.000 & 0.133 & 0.278 \\
\hline GDP & 0.144 & 0.000 & 0.074 & 0.214 \\
\hline Trade & 0.143 & 0.006 & 0.041 & 0.246 \\
\hline constant & 0.079 & 0.469 & -0.135 & 0.294 \\
\hline
\end{tabular}

Source: own elaboration in Stata.

The use of a particular econometric estimator does not affect the results of the study. However, the methodological advances are required to allow for causal interpretations of VC drivers and control for mediation effects in studied variables. The obtained result may be altered, as the number of studies increases that uses IV and other, more sophisticated methods.

There is no significant difference between the VC drivers' effect on early-stage versus late-stage $V C$ investments. The finding argues that $V C$ is not heterogeneous across stages. The result may be affected by the issue of defining the stage of VC. Early-stage deals are not always disclosed and may be underrepresented in VC databases (Devigne et al., 2018). Firstly, the level of disclosure in developing countries is generally lower. Secondly, the use of angel investing as an alternative to VC for earlystage deals is increased in weak legal environments (Cumming \& Zhang, 2019).

As discussed in the theory section, the choice of the VC determinant impacts the findings. This result is consistent with the initial FAT-PET estimation, in which technological opportunities show the largest significant effect. Surprisingly, informal institutions show the second highest effect. The positive effect is also observed for the variable trade, which represents the openness of the economy. This variable was quantitatively analysed in the literature review for the first time. The positive significant effect of GDP, financial market conditions and government quality supports the findings of previous studies. 


\section{CONCLUSIONS}

This article provides a thorough overview of produced results on the dynamics of VC development, and it statistically explains the causes of disparity in findings. The article collects 30 studies that shed light on how country characteristics can shape the VC market. The main research hypotheses were verified. Macroeconomic variables and technological opportunities positively affect the VC volume. Institutional variables are also important in venture market.

A methodological limitation is that meta-analysis can only correct the estimates provided by researchers. If all estimates are biased, then the meta-result will be biased as well. Furthermore, the effect of macroeconomic conditions is not one-sided. While GDP is one of the drivers of VC, venture market fosters business creation and welfare (Allen, 2012; Popov \& Roosenboom, 2013; Popov, 2014). The methodology used by the articles in this study may not capture the underlying causal relationships. Another concern is the limited number of studies, especially those considering informal institutions and developing countries.

Based on the reviewed literature, I wish to highlight several venues for future research. The number of studies on different VC drivers remains uneven for informal institutions, which are overlooked. Currently, there is a lack of proxies for cultural attitudes, which are particularly important for international investments (Devigne et al., 2018) and may be important for shaping VC policy (Grilli et al., 2019). Future research should focus on this matter, as informal institutions presented significant effects in meta-regression. The articles that used data from developing countries appeared quite recently in VC discussion, much more research is needed to study processes in developing context (Drover et al., 2017). Among the reasons are the low quality of data and immature VC markets in those regions. Replicating studies on different databases was suggested in previous literature reviews (e.g. Tykvová, 2018) as a mean to verify obtained results. The meta-analysis may be replicated with an enriched database in the future. The newest approaches that combine quantitative and qualitative analysis of previous literature (e.g. qualitative meta-analysis) may be especially helpful. There is a number of studies conducted on the firm level. An interaction between country-level and firm-level VC drivers is one of the prominent venues for future research. As mentioned above, methodological advances are required for capturing the complex relationships among institutional variables. The call for altering methodological tools already appeared in reviews by Drover et al. (2017) and Devigne et al. (2018).

The findings of this article should interest academics. It is important to control for the time period as VC is cyclical and may vary across different sample periods. Given the inconsistency of VC definitions, the international data sources are preferrable. Researchers should be very careful in defining dependent variables, especially when it comes to scaling it to GDP or population, since it may invert country VC rankings (Cumming, 2011).

The results may be also useful for practitioners and innovation policy. The increasing internationalization of VC calls for investors' attention towards institutional characteristics across countries. Legal framework and cultural distance may increase the severity of the agency problem and costs for venture capitalists. Decision-making can be altered according to macroeconomic conditions and institutional variables of a region, in which the portfolio company is domiciled. Policymakers should draw more attention to the factors that were found to be significant in VC investments. Policy should focus not only on direct antecedents of VC like technology but also enhance government quality, reduce trade restrictions, and grow financial markets. Moreover, the shaping of informal institutions may become a new way for policymakers to foster national VC markets and encourage foreign capital inflow.

\section{REFERENCES}

Aggarwal, R., \& Goodell, J.W. (2014). Cross-National Differences in Access to Finance: Influence of Culture and Institutional Environments. Research in International Business and Finance, 31, 193-211. https://doi.org/10.1016/j.ribaf.2013.09.004

Ahlstrom, D., \& Bruton, G. (2006). Venture Capital in Emerging Economies: Networks and Institutional Change. Entrepreneurship: Theory and Practice, 30(2), 299-320. https://doi.org/10.1111/j.1540-6520.2006.00122.x 
Allen, F. (2012). Trends in Financial Innovation and Their Welfare Impact: An Overview. European Financial Management, 18(4), 493-514. https://doi.org/10.1111/j.1468-036x.2012.00658.x

Armour, J., \& Cumming, D. (2006). The Legislative Road to Silicon Valley. Oxford Economic Papers, 58(4), $596-$ 635. https://doi.org/10.1093/oep/gpl007

Astakhov, A., Havranek, T., \& Novak, H. (2019). Firm Size and Stock Returns: A Quantitative Survey. Journal of Economic Surveys, 33(5), 1463-1492. https://doi.org/10.1111/joes.12335

Black, B., \& Gilson, R. (1998). Venture Capital and the Structure of Capital Markets: Banks Versus Stock Markets. Journal of Financial Economics, 47(3), 243-277.

Bonini, S., \& Alkan, S. (2012). The Political and Legal Determinants of Venture Capital Investments Around the World. Small Business Economics, 39(4), 997-1016. https://doi.org/10.1007/s11187-011-9323-x

Bottazzi, L., Da Rin, M. \& Hellmann, T. (2016). The Importance of Trust for Investment: Evidence from Venture Capital. Review of Financial Studies, 29(9), 2283-2318. https://doi.org/10.1093/rfs/hhw023

Cumming, D. (2011). Public Policy and Creation of Active Venture Capital Markets. Venture Capital, 13(1), 75-94. https://doi.org/10.1080/13691066.2010.492989

Cumming, D. (2014). Public Economics Gone Wild: Lessons from Venture Capital. International Review of Financial Analysis, 36, 251-260. https://doi.org/10.1016/j.irfa.2013.10.005

Cumming, D., Henriques, I., \& Sadorsky, P. (2016). “Cleantech” Venture Capital Around the World. International Review of Financial Analysis, 44(C), 86-97. https://doi.org/10.1016/j.irfa.2016.01.015

Cumming, D., Schmidt, D., \& Walz, U. (2010). Legality and Venture Capital Governance Around the World. Journal of Business Venturing, 25(1), 54-72.

Cumming, D., \& Vismara, S. (2017). De-segmenting research in entrepreneurial finance. Venture Capital, 19(1-2), 17-27. https://doi.org/10.1080/13691066.2016.1225910

Cumming, D., \& Zhang, M. (2019). Angel Investors Around the World. Journal of Business Studies, 50, $692-719$. https://doi.org/10.1057/s41267-018-0178-0

Devigne, D., Manigart, S., Vanacker, T., \& Mulier, K. (2018). Venture Capital Internationalization: Synthesis and Future Research Directions. Journal of Economic Surveys, 32(5), 1414-1445. https://doi.org/10.1111/joes.12276

Doucouliagos, H. (2011). How Large Is Large? Preliminary and Relative Guidelines for Interpreting Partial Correlations in Economics. Economics Series 2011/5, Deakin University, Faculty of Business and Law, School of Accounting, Economics and Finance.

Doucouliagos, H. \& Stanley, T.D. (2013). Are All Economic Facts Greatly Exaggerated? Theory Competition and Selectivity. Journal of Economic Surveys, 27(2), 316-339. https://doi.org/10.1111/j.1467-6419.2011.00706.x

Drover, W., Busenitz, L., Matusik, S., Townsend, D., Anglin, A. \& Dushnitsky, G. (2017). A Review and Road Map of Entrepreneurial Equity Financing Research: Venture Capital, Corporate Venture Capital, Angel Investment, Crowdfunding, and Accelerators. Journal of Management, 43(6), 1820-1853. https://doi.org/10.1177/0149206317690584

Félix, E., Pires, C., \& Gulamhussen, M. (2013). The Determinants of Venture Capital in Europe - Evidence Across Countries. Journal of Financial Services Research, 44(3), 259-279. https://doi.org/10.1007/s10693-012-0146-y

Glass, G. (1976). Primary, Secondary, and Meta-Analysis of Research. Educational Researcher, 5(10), 3-8. https://doi.org/10.3102/0013189X005010003

Gompers P., \& Lerner, J. (1999). What Drives Venture Capital Fundraising?. SSRN Electronic Journal. http://doi.org/10.2139/ssrn.57935

Grilli, L., Mrkajic, B. \& Latifi, G. (2018). Venture Capital in Europe: Social Capital, Formal Institutions and Mediation Effects. Small Business Economics, 51(2), 393-410. https://doi.org/10.1007/s11187-018-0007-7

Grilli, L., Latifi, G., \& Mrkajic, B. (2019). Institutional Determinants of Venture Capital Activity: An Empirically Driven Literature Review and A Research Agenda. Journal of Economic Surveys, 33(4), 1094-1122. https://doi.org/10.1111/joes.12319

Hadi, A. (1992). Identifying Multiple Outliers in Multivariate Data. Journal of Royal Statistical Society, 54(3), 761771. https://doi.org/10.1111/j.2517-6161.1992.tb01449.x

Hahn, D., Minola, T., Vismara, S., \& de Stasio, V. (2019). Financing Innovation: Challenges, Opportunities, and Trends. Foundations and Trends in Entrepreneurship, 15(3-4), 328-367. https://doi.org/10.1561/0300000085-1 
Hain, D., Johan, S. \& Wang, D. (2016). Determinants of Cross-Border Venture Capital Investments in Emerging and Developed Economies: The Effects of Relational and Institutional Trust. Journal of Business Ethics, 138(4), 743-764. https://doi.org/10.1007/s10551-015-2772-4

Havranek, T., Stanley, T., Doucouliagos, H., Bom, P., Geyer-Klingeberg, J., Iwasaki, I., Reed, W., \& Rost, K. (2020). Reporting Guidelines for Meta-analysis in Economics. Journal of Economic Surveys, 34(3), 469-475. https://doi.org/10.1111/joes.12363

Hazarika, S., Nahata, R., \& Tandon, K. (2009). Success in Global Venture Capital Investing: Do Institutional and Cultural Differences Matter? SSRN Electronic Journal, 646(06), 312-373. https://doi.org/10.2139/ssrn.1431265

Irsova, Z., \& Havranek, T. (2013). Determinants of Horizontal Spillovers from FDI: Evidence from A Large MetaAnalysis. World Development 42(C), 1-15. https://doi.org/10.1016/j.worlddev.2012.07.001

Jeng, L., \& Wells, P. (2000). The Determinants of Venture Capital Funding: Evidence Across Countries. Journal of Corporate Finance, 6(3), 241-289. https://doi.org/10.1016/s0929-1199(00)00003-1

KPMG Enterprise. (2018). Venture Pulse: Q4'18 Report. Retrieved from https://home.kpmg/xx/en/home/insights/2019/01/venture-pulse-q4-18-global-analysis-of-venture- funding.html on 20 February 2020.

KPMG Enterprise. (2020). Venture Pulse: Q3'20 Report. Retrieved from https://home.kpmg/xx/en/home/campaigns/2020/10/venture-pulse-q3.html on 25 October 2020.

Lerner, J., \& Schoar, A. (2005). Does Legal Enforcement Affect Financial Transactions? The Contractual Channel in Private Equity. Quarterly Journal of Economics, 120(1), 223-246. https://doi.org/10.1162/0033553053327443

Lerner, J., \& Tag, J. (2013). Institutions and Venture Capital. Industrial and Corporate Change, 22(1), 153-182. https://doi.org/10.1093/icc/dts050

Li, Y., Vertinsky, I. \& Li, J. (2014). National Distances, International Experience, and Venture Capital Investment Performance. Journal of Business Venturing, 29(4), 471-489. https://doi.org/10.1016/j.jbusvent.2013.08.002

Li, Y. \& Zahra, S.A. (2012). Formal Institutions, Culture, and Venture Capital Activity: A Cross-Country Analysis. Journal of Business Venturing, 27(1), 95-111. https://doi.org/10.1016/j.jbusvent.2010.06.003

Lingelbach, D. (2015) Developing Venture Capital When Institutions Change. Venture Capital, 17(4), 327-363. https://doi.org/10.1080/13691066.2015.1055060

Manigart, S., \& Wright, M. (2013). Venture Capital Investors and Portfolio Firms. Foundations and Trends in Entrepreneurship, 9(4-5), 365-570. https://doi.org/10.1561/0300000040

Masiak, C., Fisch, C., \& Block, J. H. (2020). In Which Regions Do Governmental, Independent, and Corporate Venture Capital Firms Invest? An Empirical Investigation across 402 German Regions. In Moritz, A., Block, J. H., Golla, S., \& A. Werner (Eds.), Contemporary Developments in Entrepreneurial Finance (pp. 201-227). Springer, Cham. https://doi.org/10.1007/978-3-030-17612-9_8

Mustafa, M., \& Mazhar, S. S. (2020). Determinants of Venture Capital Investment in India: A Time Series Analysis. The Review of Finance and Banking, 12(1), 19-30. http://dx.doi.org/10.24818/rfb.20.12.01.02

Nahata, R., Hazarika, S. \& Tandon, K. (2014). Success in Global Venture Capital Investing: Do Institutional and Cultural Differences Matter?. Journal of Financial and Quantitative Analysis, 49(4), 1039-1070. https://doi.org/10.1017/S022109014000568

Ning Y., Xu G., \& Long Z. (2019). What Drives the Venture Capital Investments in China?. Chinese Management Studies, 13(5), 574-602. https://doi.org/10.1108/cms-07-2017-0193

North, D.C. (1990). Institutions, Institutional Change and Economic Performance. Cambridge, UK: Cambridge University Press.

Popov, A. (2014). Venture Capital and Industry Structure: Evidence form Local US Markets. Review of Finance, European Finance Association, 18(3), 1059-1096. Retrieved from http://hdl.handle.net/10.1093/rof/rft018 on 6 July 2020.

Popov, A., \& Roosenboom, P. (2013). Venture Capital and New Business Creation. Journal of Banking \& Finance, 37(12), 4695-4710. https://doi.org/10.1016/j.jbankfin.2013.08.010

Romain, A., \& van Pottelsberghe, B. (2004). The Determinants of Venture Capital: A Panel Data Analysis of 16 OECD Countries. Centre Emile Bernheim, Research Institute in Management Science Working Paper Series, 04-015 (1). Retrieved from https://dipot.ulb.ac.be/dspace/bitstream/2013/8633/1/aro-0012.pdf on 1 March 2020.

Sargon B., \& Katircioğlu S. (2019). The Role of Innovation in Venture Capital: Empirical Evidence from European Union and EFTA Countries. Applied Economics Letters, 26(4), 335-340. https://doi.org/10.1080/13504851.2018.1470310 
Schertler, A. (2003). Driving Forces of Venture Capital Investments in Europe: A Dynamic Panel Data Analysis. Kiel Working Paper, 1172. Retrieved from https://www.econstor.eu/bitstream/10419/17695/1/kap1172.pdf on 5 March 2020.

Stanley, T.D., \& Doucouliagos, H. (2012). Meta-Regression Analysis in Economics and Business. Routledge, Oxford.

Stanley, T.D., \& Doucouliagos, H. (2015). Neither Fixed nor Random: Weighted Least Squares Meta-Analysis. Statistics in Medicine, 34(13), 2116-2127. https://doi.org/10.1002/sim.6481

Tykvová, T. (2018). Venture Capital and Private Equity Financing: An Overview of Recent Literature and An Agenda for Future Research. Journal of Business Economics, 88(3-4), 325-362. https://doi.org/10.1007/s11573-017-0874-4

Wallmeroth, J., Wirtz, P., \& Groh, A. P. (2018). Venture Capital, Angel Financing, and Crowdfunding of Entrepreneurial Ventures: A Literature Review. Foundations and Trends in Entrepreneurship, 14(1), 1-129. https://doi.org/10.1561/0300000066

Wessendorf, C. P., Schneider, J., Gresch, M. A., \& Terzidis, O. (2020). What Matters Most in Technology Venture Valuation? Importance and Impact of Non-Financial Determinants for Early-Stage Venture Valuation. International Journal of Entrepreneurial Venturing, 12(5), 490-521. https://doi.org/10.1504/IJEV.2020.111536

Zigraiova, D., \& Havranek, T. (2016). Bank Competition and Financial Stability: Much Ado About Nothing? Journal of Economic Surveys, 30(5), 944-981. https://doi.org/10.1111/joes.12131

\section{Appendix: List of the primary studies used in meta-analysis}

Bedu, N., \& Montalban, M. (2014). Analyzing the Uneven Development of Private Equity in Europe: Legal Origins and Diversity of Capitalism. Socio-Economic Review, 12(1), 33-70 https://doi.org/10.1093/ser/mwt011

Bonini, S., \& Alkan, S. (2012). The Political and Legal Determinants of Venture Capital Investments Around the World. Small Business Economics, 39(4), 997-1016. https://doi.org/10.1007/s11187-011-9323-x

Cherif, M., \& Gazdar, K. (2009). Public Institutions and Venture Capital in Europe: A Cross-Country Panel Data Analysis. International Journal of Public Sector Performance Management, 1(3), 275-294. https://doi.org/10.1504/IJPSPM.2009.029120

Cherif, M., \& Gazdar, K. (2011). What Drives Venture Capital Investments in Europe? New Results from A Panel Data Analysis. Journal of Applied Business and Economics, 12(3), 122-139. Retrieved from http://m.www.nabusinesspress.com/JABE/CherifWeb.pdf on 1 March 2020.

Cumming, D., \& Knill, A. (2012). Disclosure, Venture Capital and Entrepreneurial Spawning. Journal of International Business Studies, 43, 563-590. https://doi.org/10.2139/ssrn.1572652

Da Rin, M., Nicodano, G., \& Sembenelli, A. (2006). Public Policy and the Creation of Active Venture Capital Markets. Journal of Public Economics, 90(8-9), 1699-1723. https://doi.org/10.1016/j.jpubeco.2005.09.013

Félix, E., Pires, C., \& Gulamhussen, M. (2013). The Determinants of Venture Capital in Europe - Evidence Across Countries. Journal of Financial Services Research, 44(3), 259-279. https://doi.org/10.1007/s10693-012-0146-y

Gantenbein P., Kind A., \& Volonté C. (2019). Individualism and Venture Capital: A Cross-Country Study. Management International Review, 59(5), 741-777. https://doi.org/10.1007/s11575-019-00394-7

Geronikolaou G., \& Papachristou G. (2011). Is There an Adverse Effect of Uncertainty on Venture Capital? The European Evidence. Applied Economics Letters, 18(4), 383-388. https://doi.org/ 10.1080/13504851003670601

Grilli, L., Mrkajic, B. \& Latifi, G. (2018). Venture Capital in Europe: Social Capital, Formal Institutions and Mediation Effects. Small Business Economics, 51(2), 393-410. https://doi.org/10.1007/s11187-018-0007-7

Groh, A.P. \& Wallmeroth, J. (2016). Determinants of Venture Capital Investments in Emerging Markets. Emerging Markets Review, 29, 104-132. https://doi.org/10.1016/j.ememar.2016.08.020

Guilhon B., \& Montchaud S. (2015). The Impact of Basic Conditions on Investment in the Venture Capital Industry. Evidence from European countries. International Journal of Entrepreneurship and Innovation Management, 19, 194-214. https://doi.org/10.1504/IJEIM.2015.069957

Henrekson M., \& Sanandaji T. (2018). Stock Option Taxation and Venture Capital Activity: A Cross-Country Study. Venture Capital, 20(1), 51-71. https://doi.org/10.1080/13691066.2017.1400159 
Herrera-Echeverri, H. (2017). Public Expenditure in Research and Development and Venture Capital Commitments. Economics of Engineering Decisions, 28(3), https://doi.org/10.5755/j01.ee.28.3.13216

Herrera-Echeverri H., Haar J., \& Estevez-Bretón J.B. (2014). Foreign Investment, Institutional Quality, Public Expenditure, and Activity of Venture Capital Funds in Emerging Market Countries. Global Economy Journal, 14(2), 127-162. https://doi.org/10.1515/gej-2013-0068

Jeng, L., \& Wells, P. (2000). The Determinants of Venture Capital Funding: Evidence Across Countries. Journal of Corporate Finance, 6(3), 241-289. https://doi.org/10.1016/s0929-1199(00)00003-1

Kelly, R. (2012). Drivers of Private Equity Investment Activity: Are Buyout and Venture Investors Really So Different? Venture Capital, 14(4), 309-330. https://doi.org/10.1080/13691066.2012.688494

Leleux, Surlemont (2003). Public Versus Private Venture capital: Seeding or Crowding Out? A Pan-European Analysis. Journal of Business Venturing, 18(1), 81-104. https://doi.org/10.1016/S0883-9026(01)00078-7

Li, Y. \& Zahra, S.A. (2012). Formal Institutions, Culture, and Venture Capital Activity: A Cross-Country Analysis. Journal of Business Venturing, 27(1), 95-111. https://doi.org/10.1016/j.jbusvent.2010.06.003

Martí J., \& Balboa M. (2006). Self-regulation in European Venture Capital and Private Equity Markets. International Journal of Entrepreneurship and Innovation Management, 6(4-5), 395-411. https://doi.org/10.1504/ijeim.2006.010373

Ning, Y., Wang, W. \& Yu, B. (2015). The Driving Forces of Venture Capital investments. Small Business Economics, 44, 315-344, https://doi.org/10.1007/s11187-014-9591-3

Ning Y., Xu G., \& Long Z. (2019). What Drives the Venture Capital Investments in China? Chinese Management Studies, 13(5), 574-602. https://doi.org/10.1108/cms-07-2017-0193

Plagge, A. (2006). Public Policy for Venture Capital: A Comparison of the United States and Germany. DUV.

Precup, M. (2017). Venture capital and leveraged buyout: What is the difference in Eastern Europe? - A CrossCountry Panel Data Analysis. Romanian Journal of European Affairs, 17(2), 30-55. Retrieved from https://papers.ssrn.com/sol3/papers.cfm?abstract_id=3088490 on 1 March 2020.

Romain, A., \& van Pottelsberghe, B. (2004). The Determinants of Venture Capital: A Panel Data Analysis of 16 OECD Countries. Centre Emile Bernheim, Research Institute in Management Science Working Paper Series, 04-015(1). Retrieved from https://dipot.ulb.ac.be/dspace/bitstream/2013/8633/1/aro-0012.pdf on 1 March 2020.

Salehizadeh, M. (2005). Venture Capital Investments in Emerging Economies: An Empirical Analysis. Journal of Developmental Entrepreneurship, 10(3), 253-69. https://doi.org/10.1142/s1084946705000203

Sargon, B., \& Katircioğlu, S. (2019). The Role of Innovation in Venture Capital: Empirical Evidence from European Union and EFTA Countries. Applied Economics Letters, 26(4), 335-340. https://doi.org/10.1080/13504851.2018.1470310

Schertler, A. (2003). Driving Forces of Venture Capital Investments in Europe: A Dynamic Panel Data Analysis. Kiel Working Paper, 1172. Retrieved from https://www.econstor.eu/bitstream/10419/17695/1/kap1172.pdf on 1 March 2020.

Schröder, C. (2011). Financial System and Innovations: Determinants of Early Stage Venture Capital in Europe. In Welfens P., \& C. Ryan (Eds.), Financial Market Integration and Growth (pp. 127-158). Springer, Berlin, Germany. https://doi.org/10.1007/978-3-642-16274-9_4

Stein, E.H., \& Wagner, R.A. (2019). The development of venture capital in Latin America and the Caribbean: a comparative perspective. CEPAL Review, 18, 49-70. Retrieved from https://repositorio.cepal.org/handle/11362/44979 on 1 March 2020. 


\section{Author}

\section{Adel Dalal}

Doctoral student in Innovation Management (Higher School of Economics); lecturer at Higher School of Economics St. Petersburg (Russia). Her research interests include entrepreneurial finance, venture capital and behavioural finance.

Correspondence to: Adel Dalal, Higher School of Economics St. Petersburg, St. Petersburg School of Economics and Management, Kantemirovskaya 3A, 194100, St. Petersburg, Russia, e-mail: adalal@hse.ru or adeldalal@yandex.ru

ORCID (1) http://orcid.org/0000-0001-6682-1635

\section{Acknowledgements and Financial Disclosure}

The reported study was funded by RFBR, project number 19-310-90085. The author would like to thank the anonymous reviewers for their insightful comments, which allowed to increase the quality of the study. The author would like to express her gratitude to Prof. Slavo Radosevic and Dr. Randolph Bruno for their valuable comments for the draft version of this paper and their support at each step of the research.

\section{Conflict of Interest}

The author declares that the research was conducted in the absence of any commercial or financial relationships that could be construed as a potential conflict of interest.

\section{Copyright and License}

This article is published under the terms of the Creative Commons

Attribution - NoDerivs (CC BY-ND 4.0) License

http://creativecommons.org/licenses/by-nd/4.0/ 